\title{
Impact of precipitation intermittency on NAO-temperature signals in proxy records
}

\author{
M. Casado ${ }^{1}$, P. Ortega ${ }^{1}$, V. Masson-Delmotte ${ }^{1}$, C. Risi ${ }^{2}$, D. Swingedouw ${ }^{1}$, V. Daux ${ }^{1}$, D. Genty ${ }^{1}$, F. Maignan ${ }^{1}$, \\ O. Solomina ${ }^{3}$, B. Vinther ${ }^{4}$, N. Viovy ${ }^{1}$, and P. Yiou ${ }^{1}$ \\ ${ }^{1}$ Laboratoire des Sciences du Climat et de l'Environnement, UMR8212, CEA-CNRS-UVSQ/IPSL - CEA Saclay, \\ 91191 Gif-sur-Yvette Cédex, France \\ ${ }^{2}$ Laboratoire de Météorologie Dynamique, PMC-CNRS-ENS/IPSL, Paris, France \\ ${ }^{3}$ Institute of Geography, Russian Academy of Sciences, Moscow, Russia \\ ${ }^{4}$ Center for Ice and Climate, Niels Bohr Institute, University of Copenhagen, Copenhagen, Denmark
}

Correspondence to: M. Casado (mathieu.casado@gmail.com)

Received: 7 September 2012 - Published in Clim. Past Discuss.: 8 October 2012

Revised: 29 January 2013 - Accepted: 1 March 2013 - Published: 27 March 2013

\begin{abstract}
In mid and high latitudes, the stable isotope ratio in precipitation is driven by changes in temperature, which control atmospheric distillation. This relationship forms the basis for many continental paleoclimatic reconstructions using direct (e.g. ice cores) or indirect (e.g. tree ring cellulose, speleothem calcite) archives of past precipitation. However, the archiving process is inherently biased by intermittency of precipitation. Here, we use two sets of atmospheric reanalyses (NCEP (National Centers for Environmental Prediction) and ERA-interim) to quantify this precipitation intermittency bias, by comparing seasonal (winter and summer) temperatures estimated with and without precipitation weighting. We show that this bias reaches up to $10^{\circ} \mathrm{C}$ and has large interannual variability. We then assess the impact of precipitation intermittency on the strength and stability of temporal correlations between seasonal temperatures and the North Atlantic Oscillation (NAO). Precipitation weighting reduces the correlation between winter NAO and temperature in some areas (e.g. Québec, South-East USA, East Greenland, East Siberia, Mediterranean sector) but does not alter the main patterns of correlation. The correlations between $\mathrm{NAO}, \delta^{18} \mathrm{O}$ in precipitation, temperature and precipitation weighted temperature are investigated using outputs of an atmospheric general circulation model enabled with stable isotopes and nudged using reanalyses (LMDZiso (Laboratoire de Météorologie Dynamique Zoom)). In winter, LMDZiso shows similar correlation values between the NAO and both the precipitation weighted temperature and $\delta^{18} \mathrm{O}$ in precipitation, thus sug-
\end{abstract}

gesting limited impacts of moisture origin. Correlations of comparable magnitude are obtained for the available observational evidence (GNIP (Global Network of Isotopes in Precipitation) and Greenland ice core data). Our findings support the use of archives of past $\delta^{18} \mathrm{O}$ for NAO reconstructions.

\section{Introduction}

The North Atlantic Oscillation (NAO) is known to have large impacts on mid to high latitudes climate, affecting daily to seasonal patterns of precipitation or temperature (Wanner et al., 2001; Hurrell et al., 2003). This is related to the associated shift in the storm track path leading to a quadrupole of surface temperature anomalies, consisting of a northern "seesaw" between northern Europe and North America, and a southern seesaw with nodes centered in the Mediterranean area and the southeastern United States (Pinto and Raible, 2012). While winter NAO has long been reported to affect Northern Hemisphere climate, the impacts of summer NAO have also been depicted in specific regions such as Europe and Greenland (Folland et al., 2009). Instrumental records document large interannual and decadal variations in the NAO index (Jones et al., 1997), usually defined as the pressure difference between the Azores high and the Icelandic low (Hurrell, 1995). Obtaining longer records is crucial to assess the natural spectrum of NAO variability and its response to external forcings (such as changes in solar 
and volcanic activity, or anthropogenic perturbations) and to evaluate the ability of climate models to capture the NAO variability (IPCC, 2007).

Over the last $15 \mathrm{yr}$, several studies have combined different sets of documentary data and paleoclimate information in order to propose reconstructions of pre-instrumental NAO variability (Appenzeller et al., 1998; Glueck and Stockton, 2001; Cook et al., 2002; Casty et al., 2007; Trouet et al., 2012, 2009; Küttel et al., 2011; Pinto and Raible, 2012; Luterbacher et al., 1999, 2000, 2001, 2002). These studies have used information related to precipitation and/or temperature in seasonal to annually resolved archives, such as dendrochronological series or Greenland ice core accumulation. Some stalagmites possess annual laminae (visible and/or fluorescent) which are used to construct precise chronologies of the past decades or centuries (Baker et al., 1993; Genty, 1993; Fleitmann et al., 2009). Thicknesses (from $\sim 0.01$ to $1 \mathrm{~mm} \mathrm{yr}^{-1}$ ) that are controlled by rainfall and temperature have been used as proxy for high resolution climate reconstructions (Munoz et al., 2009; Tan et al., 2006). Among the rare examples that used stalagmite layer thickness, the one from the Uamh Cave system (North Scotland) showed significant correlation between fluorescent laminae thickness and winter instrumental NAO index (Proctor et al., 2000; Baker et al., 2002; Baldini et al., 2006) and, combined with tree ring data from Morocco, was used to derive fluctuations of NAO during the last millennium (Trouet et al., 2009). The reliability of air temperature-sensitive and precipitation-sensitive proxies to reconstruct the NAO has been assessed and compared in a climate simulation for the last $490 \mathrm{yr}$ (Zorita and González-Rouco, 2002), suggesting that the precipitation proxies lead to more robust reconstructions. It should be noted, however, that proxy records dependent on hydrology are likely influenced both by dynamical and thermal changes (since specific humidity depends strongly on local temperature), as was shown for Maunder Minimum simulations (Yoshimori et al., 2006). Such proxy records cannot therefore be interpreted exclusively in terms of past circulation changes.

All NAO reconstructions show large multidecadal variability. However, prior to the 19th century, they show a lack of consistency (Pinto and Raible, 2012). This may be due to the influence of other modes of variability, which can affect North Atlantic climate such as the Atlantic Multidecadal Oscillation (Delworth and Mann, 2000), to variable teleconnections (Raible et al., 2006), to the different source datasets (Zorita and González-Rouco, 2002) and methodologies employed (Lehner et al., 2012). One way to reduce uncertainties is to expand the source data (type of proxies and spatial coverage) used for such reconstructions.

Recently, a significant imprint of NAO has been identified in precipitation isotopic composition $\left(\delta^{18} \mathrm{O}\right)$ in Greenland ice core records (Barlow et al., 1993; Vinther et al., 2003a, 2010), both in monthly precipitation $\delta^{18} \mathrm{O}$ data from central Europe (Baldini et al., 2008) and in daily $\delta^{18} \mathrm{O}$ data from Norway (Theakstone, 2011). Simulations conducted with general or regional atmospheric models equipped with the explicit representation of water stable isotopes have also depicted a clear signature of NAO in precipitation $\delta^{18} \mathrm{O}$ over Europe (Field, 2010; Langebroek et al., 2011), Greenland (Sjolte et al., 2011) and Svalbard (Divine et al., 2011). This imprint of the NAO is also observed in a growing number of tree ring cellulose isotope studies, from Europe (Treydte et al., 2007; Saurer et al., 2012; Hangartner et al., 2012) to Siberia (Sidorova et al., 2010). A recent study also describes a relationship between a high resolution record of Red Sea coral $\delta^{18} \mathrm{O}$ and the NAO (Felis and Rimbu, 2010). All these findings motivate the combined use of direct (ice cores) and indirect (e.g. tree ring cellulose, speleothem calcite or fluid inclusions, coral aragonite) archives of precipitation isotopic composition to reconstruct past NAO variability.

While precipitation $\delta^{18} \mathrm{O}$ is related to temperature, it is an integrated tracer of the water cycle (Jouzel, 2003). In mid and high latitudes, its variability is driven by atmospheric distillation, which is related to condensation temperature. Continental recycling (van der Ent et al., 2010) can also affect the precipitation isotopic composition. Likewise, changes in air mass trajectories can strongly impact precipitation $\delta^{18} \mathrm{O}$ (Sodemann et al., 2008). Such effects can be evaluated using second order tracers such as deuterium excess (Kurita, 2011) and ${ }^{17} \mathrm{O}$-excess (Landais et al., 2012), or quantified using isotopic models (Sturm et al., 2010). Here, we aim to quantify another source of uncertainty, related to precipitation intermittency. Indeed, precipitation $\delta^{18} \mathrm{O}$ can only record climate information when precipitation occurs. Because temperature and precipitation can co-vary at daily, seasonal or interannual timescales, this precipitation intermittency bias may distort the original NAO-temperature signal in climate archives. This source of uncertainty was recently investigated for Greenland, using atmospheric reanalyses (Persson et al., 2011). It was shown that precipitation intermittency (fraction of summer/winter snowfall and its interannual variability) explained many aspects of NAO-isotope relationships in different Greenland ice core sites. A number of recent studies have highlighted the importance of precipitation and temperature covariance at synoptic scales (Sime et al., 2008; Persson et al., 2011).

In order to assess the impact of precipitation intermittency bias on temperature-NAO relationships, we need to have access to daily, coherent and global precipitation and surface air temperature datasets. For this purpose, we used different sources of information: (i) two atmospheric reanalysis datasets and (ii) a simulation conducted with an atmospheric model equipped with water stable isotopes. The use of atmospheric reanalyses ensures a physical and dynamical consistency between temperature and precipitation, and largescale weather patterns. However, the precipitation amounts calculated by the reanalyses are prone to biases of the models they are based on, despite the assimilation of several observational products. This motivates a comparison among the 

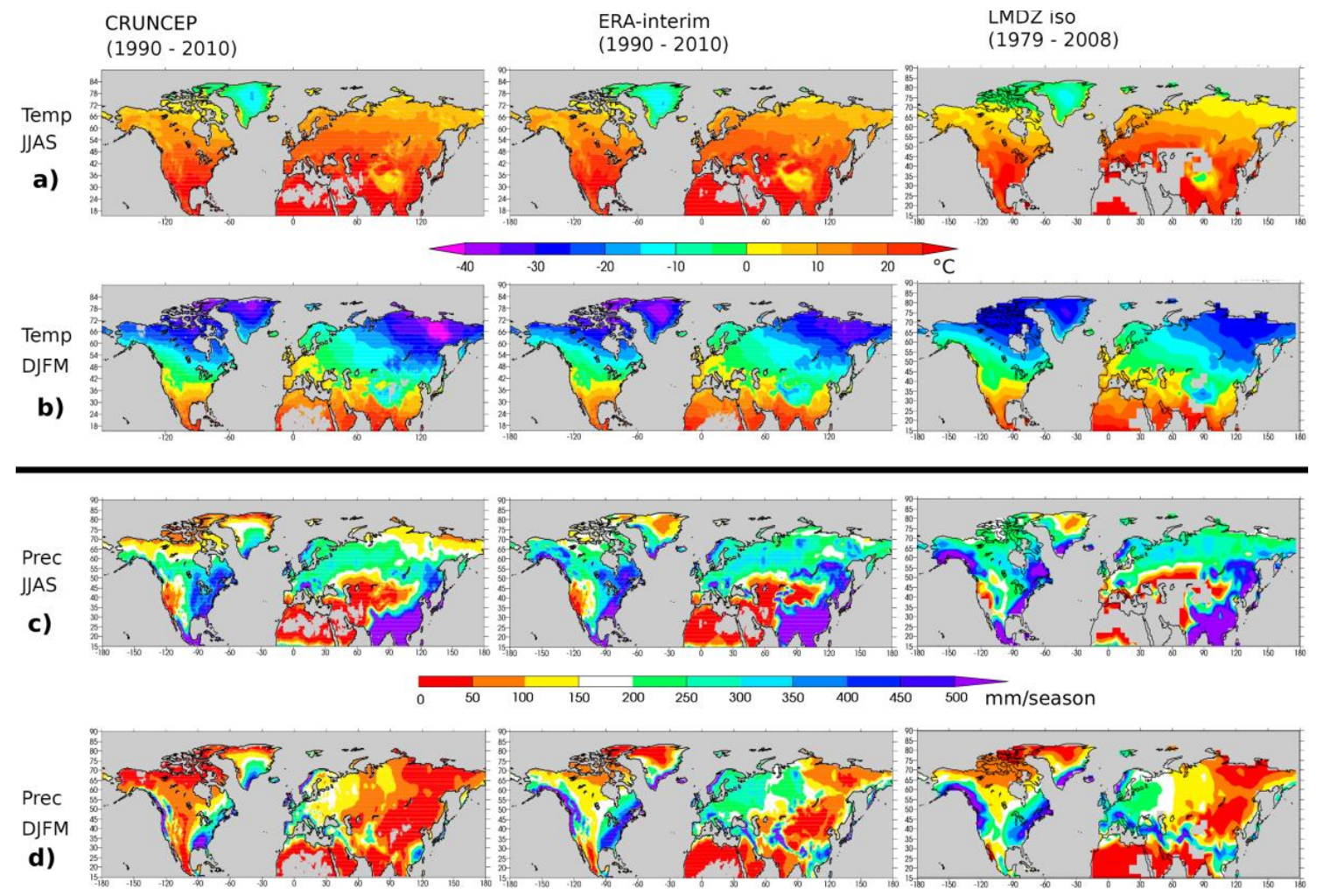

Fig. 1. Climatologies of CRU-NCEP, ERA-interim, and LMDZiso fields of (a) JJAS temperature $\left({ }^{\circ} \mathrm{C}\right)$; (b) DJFM temperature $\left({ }^{\circ} \mathrm{C}\right)$; (c) JJAS precipitation $\left(\mathrm{mm} \mathrm{season}^{-1}\right.$ ) and (d) DJFM precipitation $\left(\mathrm{mm} \mathrm{season}^{-1}\right.$ ). The reference periods correspond to $1990-2010$ in the atmospheric analyses and to 1979-2008 in LMDZiso. Note that all the regions with seasonal precipitation values lower than $5 \mathrm{~mm} \mathrm{season}^{-1}$ have been masked out.

different reanalysis datasets (see Fig. 1) and with observational data from meteorological stations (see Supplement, Sect. A). The use of an isotope-enabled model (LMDZiso (Laboratoire de Météorologie Dynamique Zoom)), nudged to 3-dimensional wind patterns reanalyses from ERA40, then allows us to quantify the relationships between precipitationweighted temperature and precipitation isotopic composition, and to compare directly the simulated NAO-isotope relationships with observations.

After a description of the databases, simulations and methods (Sect. 2), the bias induced by precipitation intermittency is quantified at different timescales, for winter and summer (Sect. 3). This focus on December-March (DJFM) and JuneSeptember (JJAS) is motivated by the reported impacts of NAO on seasonal climate variables, and by the ability of some proxy records to resolve seasonal variations (e.g. ice cores). We then analyse the impact of precipitation intermittency on correlations between temperature and NAO and compare our results with observations. Finally, key conclusions and perspectives are presented in Sect. 4. Additional information is available in the Supplement.

\section{Databases, simulations and methods}

\subsection{Atmospheric reanalyses datasets}

Two reanalysis datasets are used in this study: (i) NCEP data (Kalnay et al., 1996), modified for consistency with CRU TS.3.1 (Climate Research Unit Time Series) temperature data (Maignan et al., 2011); and (ii) ERA-interim data (Dee et al., 2011).

The first dataset, CRU-NCEP, is based on a combination of the NCEP (National Centers for Environmental Prediction) reanalysis (Kalnay et al., 1996), covering the period 1948 to 2010 with a 6 -hourly $2.5 \times 2.5^{\circ}$ spatial resolution, and the CRU TS 3.1 dataset from the University of East Anglia (Mitchell and Jones, 2005), which provides monthly climate variables (temperature, precipitation, cloudiness and relative humidity) from 1901 to 2010 with $0.5 \times 0.5^{\circ}$ spatial resolution for both latitudes and longitudes on land areas. The daily NCEP fields are interpolated to the finer $0.5 \times 0.5^{\circ} \mathrm{spa}-$ tial grid, and their climatology is corrected for biases with the monthly fields from CRU TS 3.1 (for further details see http://dods.extra.cea.fr/data/p529viov/cruncep/). The objective of CRU-NCEP is double: first, to correct for biases in the NCEP dataset because fields such as precipitation or solar 
radiation are produced by the atmospheric model and can show significant biases; second, to improve the resolution of the dataset and better account for the effect of orography, taking advantage of the higher CRU dataset resolution. Thus, this final mixed CRU-NCEP dataset provides a fine resolution both in time (6-hourly) and space $\left(0.5^{\circ}\right)$.

In order to assess the robustness of our results, the analysis will be also extended to the ERA-Interim reanalysis (Dee et al., 2011), with a resolution of $0.72 \times 0.72^{\circ}$ for the period from 1990 to 2010. Comparisons between different reanalyses products (see Sect. 2.4) and observations have stressed the good performance of the ERA-interim spatial and temporal distribution of precipitation (Bosilovich et al., 2008; Ma et al., 2009; Chen et al., 2011). The performance of the reanalyses depends on the assimilation of humidity observations (Andersson et al., 2007; Janowiak et al., 2010) and the physical parameterization of the models, especially regarding atmospheric convection (Jung et al., 2010). Caveats in the representation of soil moisture in the NCEP reanalyses have been related to an overestimation of summer land precipitation, due to excessive convective precipitation (Serreze and Hurst, 2000). At the monthly scale, these studies systematically report better performance for winter than for summer precipitation.

The robustness of the results obtained using products of atmospheric reanalyses has been assessed by comparing the difference between precipitation weighted temperature and seasonal mean temperature (see Sect. 2.5) from these datasets, with the same calculations performed using the ECA\&D (European Climate Assessment and Dataset, http: //eca.knmi.nl) daily station data (See Supplement, Sect. A, Fig. S1).

\subsection{LMDZiso simulation}

To compare the correlations between NAO and precipitation weighted temperature with those related to changes in precipitation isotopic composition, a simulation for the period 1979-2008 with the isotopic model LDMZiso (Risi et al., 2010) was employed (Fig. 1). The simulation was nudged with the 3-dimensional horizontal winds of ERA-40 (Uppala et al., 2005) during the period 1979-2002, and from ECMWF (European Centre for Medium-Range Weather Forecasts) operational analyses thereafter. In both cases, the horizontal winds were interpolated from a regular $1.125 \times 1.125^{\circ}$ grid to the resolution of LMDZiso before the nudging was applied. No noticeable discontinuity due to the change in the nudging data was observed (Risi et al., 2010). Nudging with the reanalyses allows for a better representation of the synoptic and interannual variability of both $\delta^{18} \mathrm{O}$ and temperature at mid and high latitudes. The LMDZiso simulation reproduces reasonably well the spatial and seasonal variations of $\delta^{18} \mathrm{O}$ (Risi et al., 2010). However, its simulated winter precipitation $\delta^{18} \mathrm{O}$ is overestimated over central Greenland, associated to a warm temperature bias $\left(2.6\right.$ and $6.4^{\circ} \mathrm{C}$ as compared respectively to CRU-NCEP and ERA-Interim; see Fig. 1b), also observed in other isotopic general circulation models (Steen-Larsen et al., 2011). Note that indeed the model resolution is relatively coarse (i.e. $2.5 \times 3.75^{\circ}$ and 19 vertical levels) compared to the two reanalysis datasets, which are thereby expected to better represent small-scale climatic features, especially those related to complex orography. As for the two reanalyses, both the temperature biases due to precipitation intermittency and the spatial features of the associated NAO fingerprint will be also analysed in the LMDZiso outputs.

\subsection{Precipitation isotopic composition datasets}

Monthly precipitation $\delta^{18} \mathrm{O}$ data are available from the Global Network of Isotopes in Precipitation (GNIP) stations (Rozanski et al., 1993) and can be used to assess the robustness of the LMDZiso results. A key limitation arises from the brevity and discontinuities of most GNIP station records, with multidecadal information being mostly provided by a few central European stations (Baldini et al., 2008). Our analysis will therefore focus on stations located north of $20^{\circ} \mathrm{N}$, where the main centres of action of the NAO are located. A subset of GNIP stations, for which summer and winter measurements are available for at least $10 \mathrm{yr}$, was selected to assess the link to the NAO variability. This 10 -yr threshold yields a reasonable spatial coverage and allows for statistical analysis. The data have been combined and re-gridded on a $1 \times 1^{\circ}$ grid, resolving the high station density over central Europe. When more than one station is available in a grid point, only the station with the longest record is employed. Under these conditions, 60 stations are finally selected. The selected locations are summarised in the Supplement (Sect. B, Tables S1 and S2) and their actual locations are shown in Fig. 8 (right column).

Greenland ice core data are also used as an independent source of information, but most records are available only prior to e.g. 1970, limiting the comparison with the most recent and reliable part of the reanalyses and with LMDZiso datasets (Sodemann et al., 2008; Sjolte et al., 2011). In this analysis, we used a compilation of winter and summer ice core data (Vinther et al., 2010) complemented by the new data from the NEEM (North Eemian) ice core (Steen-Larsen et al., 2011). Specific details on the ice core data are given in Supplement Table S3.

\subsection{Climatologies}

Figure 1 displays the climatologies of CRU-NCEP (19902010), ERA-Interim (1990-2010) and LMDZiso (19792008) for summer (JJAS) and winter (DJFM). Summer temperatures (Fig. 1a) show a general good agreement among the 3 datasets. As compared to the reanalyses, LMDZiso exhibits a cold bias, most obvious in regions of steep orography such as the Tibetan Plateau, and also at high latitudes 
(e.g. northern Russia, Alaska and Nunavut). For winter temperature (Fig. 1b), the different datasets are also very coherent. An opposite bias is observed for LMDZiso with respect to the reanalyses, with comparatively higher temperatures around Greenland and Northern Yakutia. In these areas, significant discrepancies are found between ERA-interim and CRU-NCEP.

The climatologies of precipitation (Fig. 1c, d) reveal larger differences among the three datasets. Despite the large differences in resolution, the largest degree of agreement, both for summer and winter, occurs between LMDZiso and ERAInterim. This points to a secondary role of orography as compared to the representation of large-scale dynamics, which is forced to be consistent through the nudging technique. The three datasets share common robust features, such as the distribution of summer precipitation across the Mediterranean Basin, northern Europe, southern and central Asia, the United States and southern Greenland, as well as the representation of winter precipitation in the coastal areas of Europe, North America (at midlatitudes) and South-East Greenland. The largest discrepancies again appear at high latitudes, in regions such as western Russia and northern Greenland.

\subsection{Calculation of precipitation-weighted temperature}

The biases associated with precipitation intermittency are expected to differ from one season to the next, for instance due to different radiative impacts of cloudiness. For each given year, we have therefore calculated seasonal (DecemberMarch, DJFM and June-September, JJAS) temperature and precipitation-weighted temperature averages.

The precipitation weighting was tested at three temporal resolutions: the 6-h step dataset, and both the daily and monthly averages of temperature and precipitation. It is calculated with the simplest approach:

$$
\begin{aligned}
& T_{p, t}(\text { year, season, lat, lon }) \\
& =\frac{\sum_{t} T_{2 \mathrm{~m}}(t, \text { lat, lon }) \times p(t, \text { lat, lon })}{\sum_{t} p(t, \text { lat, lon })},
\end{aligned}
$$

where $t$ represents the different temporal resolution (6hourly, daily or monthly means); lat and lon are the latitude and longitude, respectively; $T_{2 \mathrm{~m}}$ is the $2 \mathrm{~m}$ air temperature and $p$ the precipitation amount (which is the sum of rainfall and snowfall amounts). Differences between the 6-hourly and daily precipitation-weighted temperature may arise from differences in the diurnal cycle of precipitation and temperature; differences between the daily and monthly precipitation weighted temperature are expected to be caused by the covariance of temperature and precipitation at synoptic scales.

This calculation is performed for all CRU-NCEP, ERAinterim and LMDZiso datasets, and the respective results are compared and discussed in Sect. 3. Precipitation weighted temperature is not computed in grid points where annual precipitation is less than $5 \mathrm{~mm}$. This threshold allows avoiding artefacts associated with very rare precipitation events in ar-

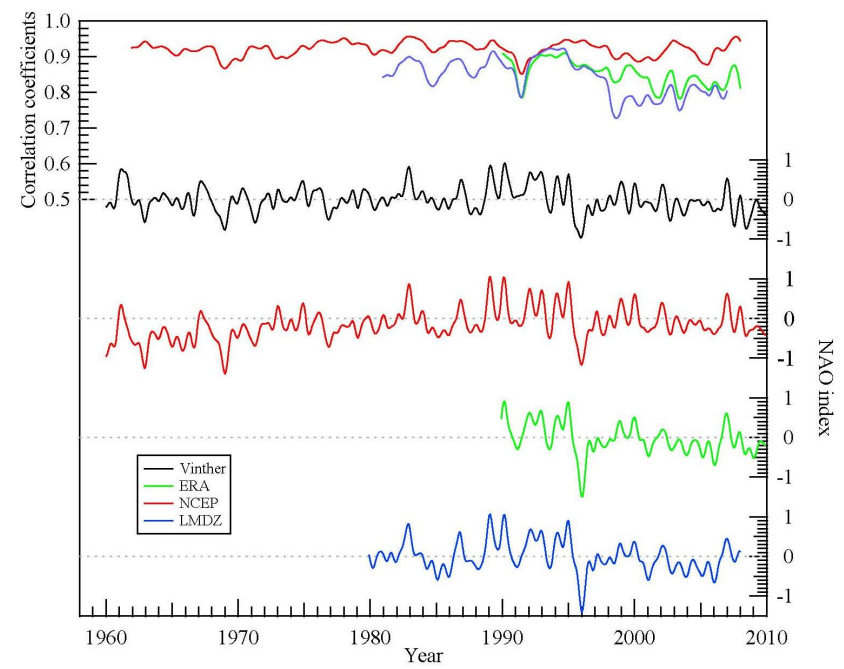

Fig. 2. Monthly NAO indices from 1960 to 2010 defined as normalized pressures differences between Gibraltar and Reykjavik. The lower panels depict individual time series: instrumental data (black), CRU-NCEP (red) and ERA-interim (green) analyses, and LMDZiso simulation (blue). An 11-month binomial filter was applied on monthly data to stress annual minima and maxima. Upper panel: 25 month running correlation coefficient between the reference instrumental time series and ERA-interim (green), CRUNCEP (red) and LMDZiso (blue) outputs.

eas such as the Sahara; it does not affect NAO-influenced areas. The temperature biases associated to each weighting resolution are compared for CRU-NCEP in the Supplement (Sect. C). For the rest of the analysis we will exclusively focus on the precipitation intermittency bias calculated from daily values.

\subsection{North Atlantic Oscillation index}

Our reference NAO time series is the instrumental index defined by Jones et al. (1997) and expanded by Vinther et al. (2003b), calculated as the normalised sea level pressure difference between Gibraltar/Cadiz and Reykjavik. Following this definition, NAO indices were computed from CRUNCEP, ERA-interim and LMDZiso datasets. All these time series correlate well with the instrumental data, as indicated by correlation coefficients above 0.8 and around 0.9 for CRU-NCEP (Fig. 2). Small differences may be caused by the resolution of atmospheric models and the choice of individual atmospheric model grid points. This coherency justifies the use of the reanalyses and LMDZiso for investigating NAO-climate relationships in a realistic framework. However, the small differences require that, for a given dataset, we use the NAO index most consistent with the dataset (e.g. LMDZiso surface climate parameters will be correlated with LMDZiso NAO index; GNIP data with the instrumental NAO index, and so forth). 
The choice of an index based on pressure differences is questionable due to the shifting positions of the NAO pressure centers of action, both at the seasonal (Folland et al., 2009) and decadal scales (Raible et al., 2006; Pinto and Raible, 2012). An alternative definition of the NAO index is based on the first principal component of the sea level pressure field. Although during the summer both the variance explained and the amplitude of the NAO diminishes substantially relative to winter (Hurrell et al., 2003), this pattern is still captured as the leading mode of SLP (sea level pressure) in the North Atlantic, both in the reanalyses and most climate model simulations (Bladé et al., 2012). Note that the dipole structure is displaced towards the northeast during summer, with maximum positive anomalies in Scandinavia, and negative ones over the Arctic Ocean (Supplement, Sect. D, Figs. S3, S4 and S5). This shift might introduce differences with respect to the station-based NAO index.

Hereafter, "NAO index" refers to this original stationbased definition.

\subsection{Statistical analyses}

We focus on interannual relationships at the seasonal scale (December-March, DJFM and June-September, JJAS). For each grid point, the interannual relationships between DJFM or JJAS temperature, precipitation, precipitation-weighted temperature (using daily precipitation and temperature data) and the NAO index was quantified using the Pearson correlation coefficient, using the CDAT (Climate Data Analysis Tools) 3.3 toolbox (http://www2-pcmdi.llnl.gov/cdat). The significance of linear correlations was assessed with a Student's $t$ test, which takes into account the series autocorrelation to calculate the actual degrees of freedom. Note that correlations were investigated for different time periods, depending on the dataset (e.g. 1979-2008 with LMDZiso, 1990-2010 for ERA-interim). We have used the NCEP dataset to assess the stability of correlations over different time periods (1950-1970, 1970-1990 and 1990-2010; see Sect. 3.5). This allowed a systematic comparison of the results obtained from NCEP and ERA-interim over the time period 1990-2010. Correlations with the GNIP observation were calculated for different time periods when data were available for at least $10 \mathrm{yr}$.

\section{Results and discussion}

In this section, we describe the calculated mean precipitation intermittency biases (defined as $T_{p}-T$ ) and also its influence on the NAO-temperature relationship for each season (JJAS and DJFM).

\subsection{JJAS temperature biases}

In summer, precipitation intermittency produces limited biases (in terms of spatial extent and in terms of magnitude) at mid and high latitudes (Fig. 3a). While NCEP suggests a small positive bias for high latitude lands, this result is neither supported by ERA-Interim (positive bias only for Greenland), nor by LMDZiso (no bias). By contrast, all datasets depict a cold bias on western North America and around the Mediterranean Sea, albeit with different magnitudes (smaller for NCEP and larger for LMDZiso). Such a cold bias is simulated in areas characterized by low mean summer precipitation (Fig. 1a) and may be linked with the albedo effect of clouds, or the impact of evaporation on land temperature (Hirschi et al., 2011).

By computing its interannual standard deviation (Fig. 3c), we identify regions where the temperature bias is more variable, and therefore where precipitation weighting is more sensitive to internal climate variability. During summer, the regions with the largest standard deviations are confined to the Pacific Coast of the United States, the Mediterranean Basin and central Asia. This is observed in the three datasets, although with higher values in LMDZiso. Less coherent results are obtained for the winter season, when the areas with largest standard deviations vary from one dataset to another. Despite these discrepancies, large standard deviations are found for northern North America (including Greenland), and northern Asia, as well as North Africa - India (for ERA-Interim and LMDZiso). LMDZiso also produces large standard deviations near Baffin Island.

\subsection{Impact of precipitation intermittency on JJAS NAO-temperature relationships}

The correlation patterns between the NAO and the fields of JJAS precipitation, temperature, precipitation weighted temperature and $\delta^{18} \mathrm{O}$ are displayed in Fig. 4 for the reanalyses and LMDZiso.

Correlations are generally patchy and weak for precipitation (Fig. 4a), with significant negative correlations depicted by reanalyses for Western Europe and northern Siberia; LMDZiso does not capture the strength of these relationships. Larger areas are detected for NAOtemperature relationships (Fig. 4b), mostly in northern North America, Greenland (especially South Greenland) and NE Siberia. LMDZiso displays a particularly strong correlation in southern Greenland. For precipitation-weighted temperature (Fig. 4c), correlations are weaker and more patchy, with significant negative correlation represented in some of the datasets for NW North America, some areas of Greenland, and, in reanalyses, NE Siberia.

In LMDZiso, strong negative correlations are simulated between JJAS NAO and $\delta^{18} \mathrm{O}$ (Fig. 4d) for NW North America, NE North America, Greenland, and E Siberia. The fact that these correlations are stronger than for weighted temperature suggests that summer NAO also affects isotopic composition due to air mass origins; this has not yet been explored from specific trajectory calculations. The results obtained with LMDZiso must be taken with caution, due to the 

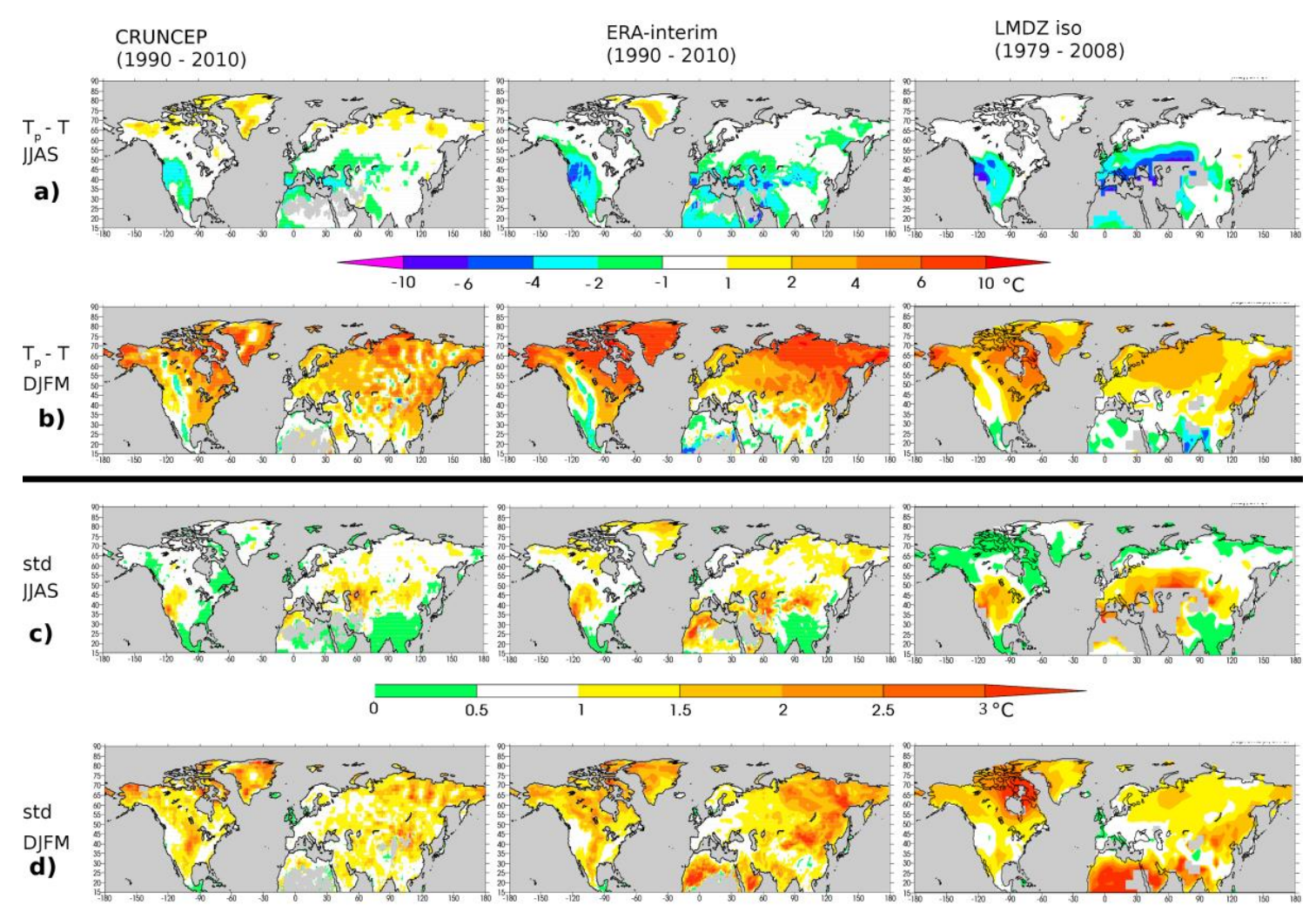

Fig. 3. (a) Mean precipitation intermittency bias for JJAS (in ${ }^{\circ} \mathrm{C}$ ), defined as the difference between the daily precipitation weighted temperature $\left(T_{p}\right)$ and the mean seasonal temperature $(T)$ in CRU-NCEP, ERA-interim and LMDZiso; (b) The same but for DJFM; (c, d) The same as in the upper panels but showing the interannual standard deviation (std) of the biases in JJAS and DJFM, respectively.

fact that the simulated correlations are stronger than observed (Table S3, Fig. 8a).

The seasonal shift in the position of the centers of action of the NAO, which are displaced to the northeast during summer (Fig. S3), can have an influence in the correlation patterns. This sensitivity to the position of the centers of action is assessed in Figs. S4 and S5, showing the corresponding correlation patterns for the NAO indices defined as the leading PC (principle components) of SLP in LMDZiso. In summer (Fig. S4), this alternative NAO index produces significant correlations in northern Europe not previously observed, and weaker values over Greenland. All these changes are consistent with the new position of the SLP dipole.

While small, the precipitation intermittency bias complicates the signal detection. From these investigations, we cannot rule out the possibility of estimating past changes in JJAS NAO based on isotopic proxies, from selected areas (NW, NE North America, E Siberia, Greenland) where $T, T_{p}$ and $\delta^{18} \mathrm{O}$ are related to NAO.

\subsection{DJFM bias}

Over most Northern Hemisphere land areas, wet days are warmer than the average winter days, and this bias reaches up to $6^{\circ} \mathrm{C}$ in Arctic areas such as Greenland, Alaska or
Siberia (Fig. 3b). This warm bias is consistent with the radiative impacts of water vapour and cloudiness on surface temperature. The spatial patterns of the DJFM bias are similar in CRU-NCEP, ERA-interim and LMDZiso, with a few regional differences in central Greenland and Eastern Siberia, possibly due to differences in simulated precipitation amounts (Fig. 1d). We note a specific band along the Rocky Mountains where precipitation weighting induces a cold bias, which could be related to an albedo effect of clouds and/or snow. The magnitude of the precipitation intermittency bias is much larger in ERA-interim at high latitudes (Fig. 3b). Surprisingly, LMDZiso produces a precipitation intermittency bias that is more similar to the magnitude derived from NCEP data, while its mean climate is closer to that of ERA-Interim. This might indicate that the nudging in LMDZiso is not strong enough to reproduce the timing and/or location of precipitation as in the original reanalysis, or that the results are dominated by the large temperature biases of LMDZiso at high latitudes (Fig. 1b). Altogether, robust features of the spatial pattern of precipitation intermittency bias emerge from the three datasets investigated here, with a large bias found in several areas where climate is affected by the NAO (with the exception of Europe). 

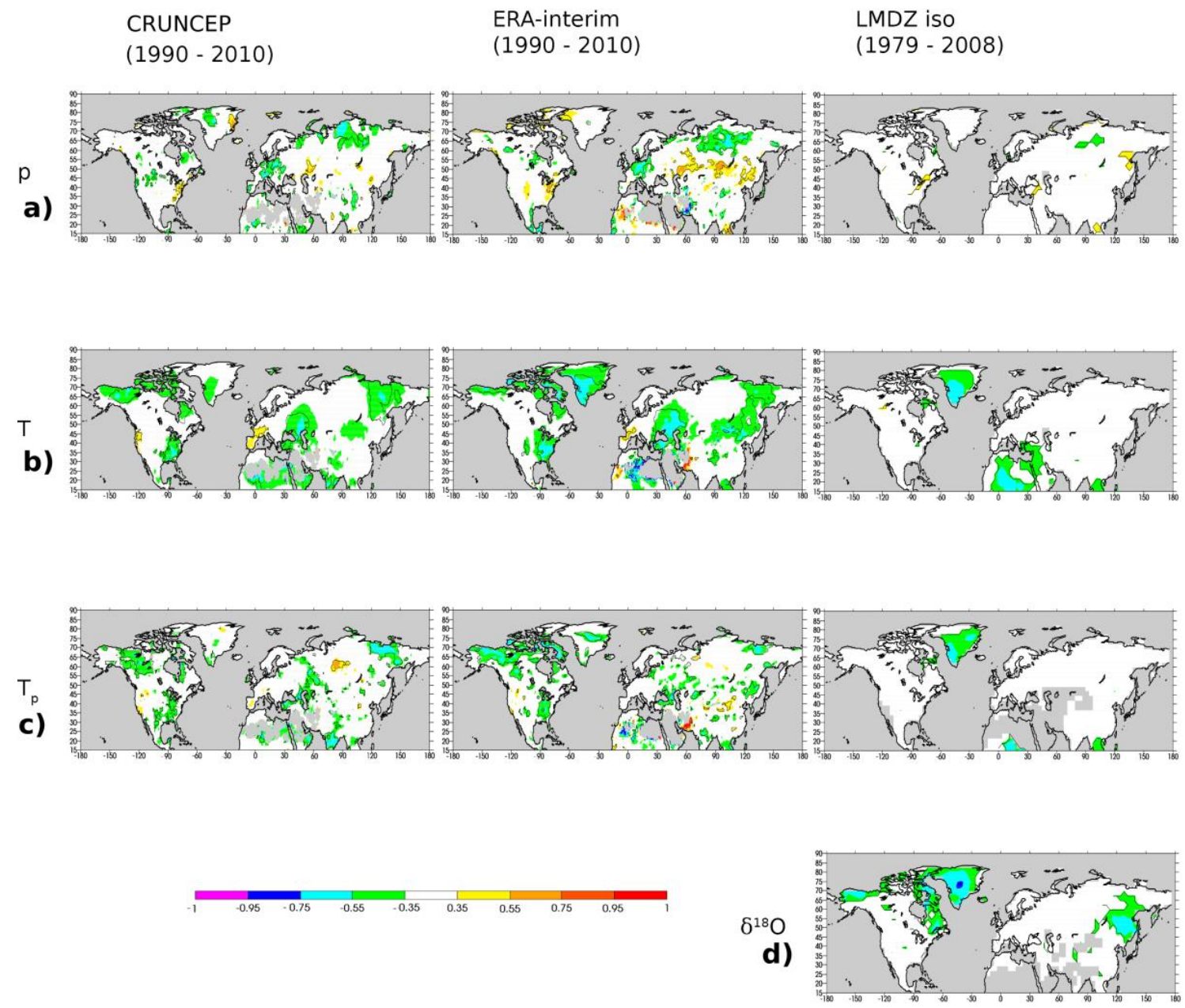

Fig. 4. Linear correlation coefficients between the respective JJAS NAO indices and the fields of (a) precipitation $(p)$, (b) temperature $(T)$ and (c) precipitation-weighted temperature $\left(T_{p}\right)$ in the CRU-NCEP (left), ERA-interim (middle) and LMDZiso (right) datasets. Significant correlations are highlighted using a Student $t$ test $(p<0.05)$ (thin black line). The correlation coefficients with the summer fields of $\delta^{18} \mathrm{O}$ are shown for the LMDZiso simulation in (d).

The interannual standard deviation of the precipitation intermittency bias is represented on Fig. $3 \mathrm{~d}$, reaching $2{ }^{\circ} \mathrm{C}$ in several areas. NCEP and ERA-interim produce large interannual variability of the winter bias in northern North America, Greenland, and Siberia, while LMDZiso produces the largest variability in NE North America and has a significantly lower standard deviation in Siberia. The magnitude of high latitude precipitation intermittency bias and its variability has a potential to distort the fingerprint of NAO in precipitation archives, which is investigated in the next subsection.

\subsection{Impact of precipitation intermittency on DJFM NAO-temperature relationships}

Figure 5 shows the comparison of the correlation coefficients between DJFM NAO and precipitation, temperature, and precipitation-weighted temperature $\left(T_{p}\right)$ as calculated for CRU-NCEP, and ERA-interim from 1990-2010 and for LMDZiso from 1979 to 2008.

Winter precipitation is positively correlated with the NAO in northern Europe (Fig. 5a), and areas of Russia in all datasets; LMDZiso seems to produce stronger correlations for Northern Europe than reanalyses. Negative correlations are also systematically produced for areas of NW North America (from Quebec to Ellesmere Island), western or South Greenland, Eastern Siberia and the Mediterranean area, where the strongest negative correlations are depicted in both reanalysis datasets.

The spatial correlation patterns of NAO with temperature (Fig. 5b) are different from the pattern previously described for precipitation. The results appear more coherent at a continental scale, with positive correlations for SE North America, western to northern Europe, Russia and central Siberia, and negative correlations for NW North America, Greenland, the southern Mediterranean land areas and Eastern 

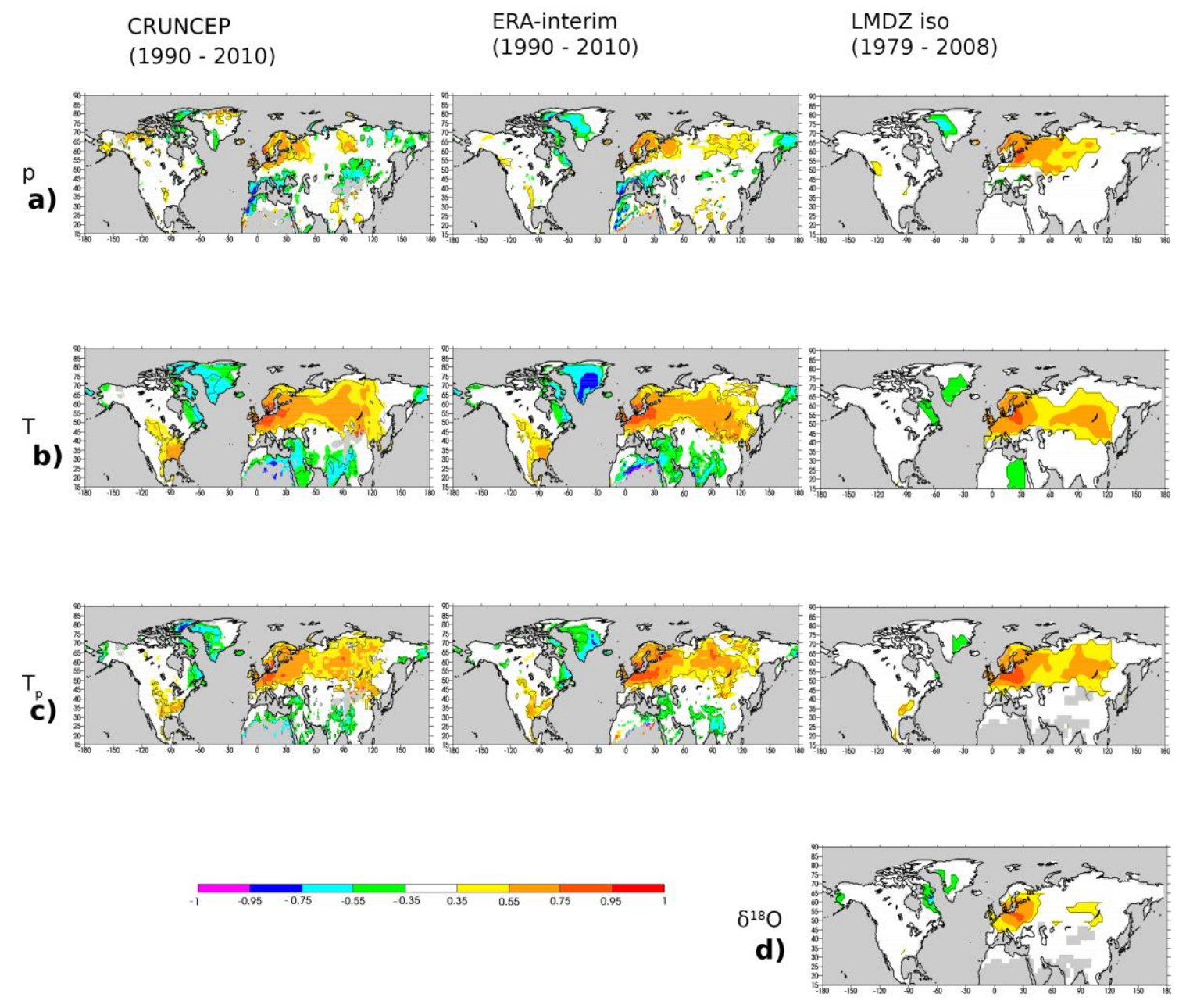

Fig. 5. The same as in Fig. 4 but for DJFM.

Siberia. While stronger negative correlations are observed in ERA-interim, especially over Greenland where the strongest negative correlation is depicted ( $R<-0.75$ for ERA), the strongest positive correlations are consistently obtained in north-western Europe $(R>0.75)$ for the three datasets. Overall, LMDZiso shows correlations of smaller amplitude (both positive and negative) than the reanalyses, only capturing the centers of action over Greenland and Eurasia.

The main patterns of NAO-temperature correlation are preserved when considering precipitation-weighed temperature (Fig. 5c), with the exception of East Greenland and East Mediterranean/Middle East areas. For LMDZiso, similar patterns of correlation are obtained for $T$ and $T_{p}$, with even a stronger signal in a large central Europe area $(R>0.75)$ and a shift in the strongest negative correlation coefficient from southern to eastern Greenland. In the reanalyses, correlations seem to be sensitive to local conditions, such as orography. As a result, in CRU-NCEP correlations appear generally reduced in Siberia/Russia, North America and Greenland. Likewise, for ERA-interim, the most remarkable differ- ences are a general reduction of correlation in Greenland and South-western Russia, but enhanced correlation coefficients to the South-East of Finland and over the Central Siberian Plateau. The difference between the different datasets seems closely related to differences in the winter precipitation climatologies (Fig. 1d). The overall spatial features described herein remain robust for the other alternative NAO definition, i.e. the leading PC of SLP anomalies in the North Atlantic (Fig. S5).

\subsection{Temporal stability of correlation}

In the previous sections, analyses were focused on the most recent period (1990-2010), where there is an overlap between our different datasets, and during which the reanalysis systems are most strongly constrained by assimilated observations. We are aware that this time interval is characterised by high DJFM NAO levels in the early 1990s. Figures 6 and 7 investigate, respectively, the stability of summer and winter NAO-climate (temperature, precipitation, and precipitation-weighted temperature) relationships 

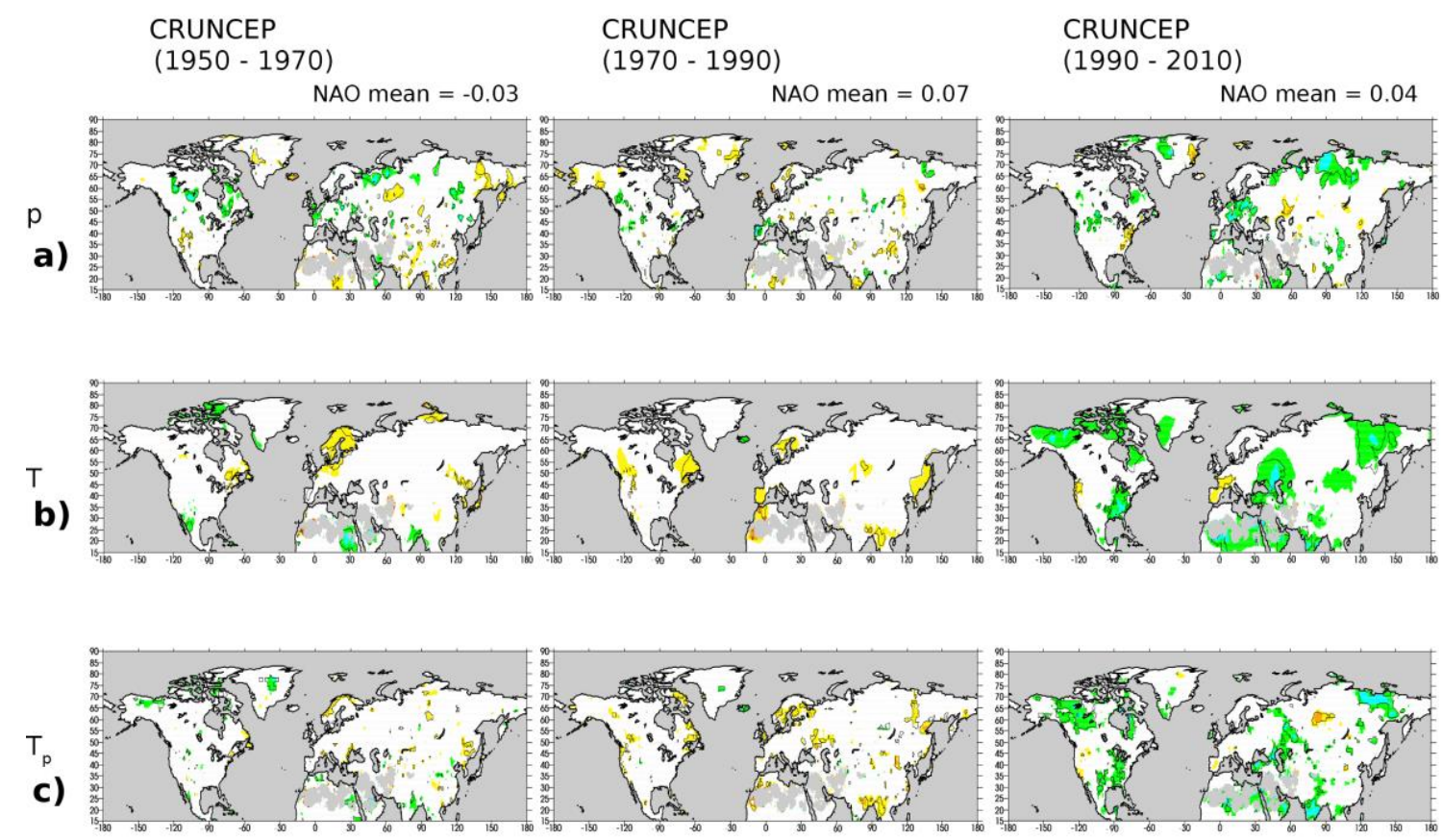

Fig. 6. The same as Fig. 4 but focused on the JJAS NAO correlations for three different time intervals in CRU-NCEP: 1950-1970, 1970-1990 and 1990-2010.

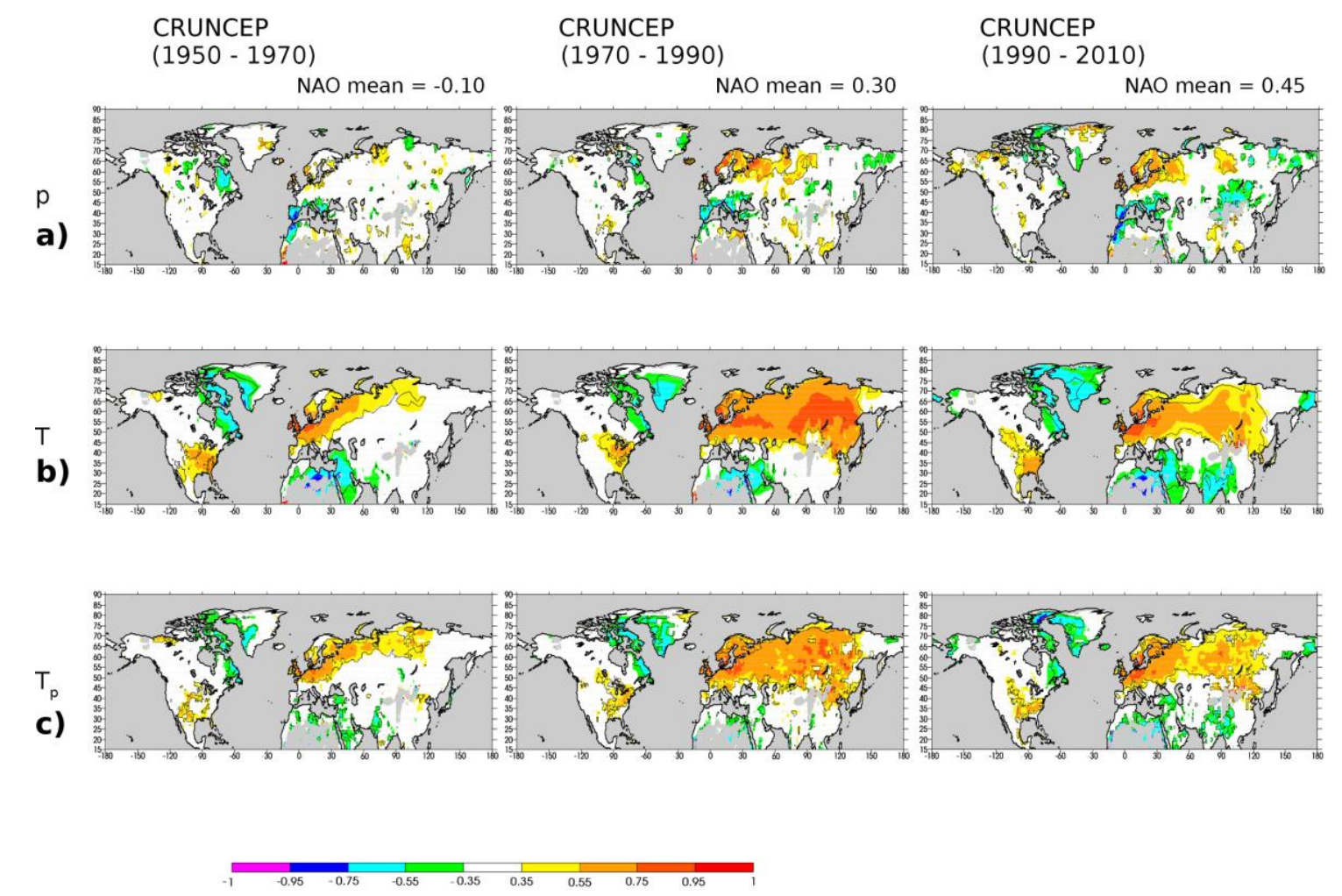

Fig. 7. The same as Fig. 6 but for the winter (DJFM). 
throughout different time periods. Three bi-decadal intervals have been compared: 1990-2010 (previously chosen for comparison with ERA-interim), and the new periods 19701990 and 1950-1970. This latter period is characterised by a weak negative NAO mean state, while the other two show strong positive mean $\mathrm{NAO}$ values.

The summer is characterised by small and unstable NAOclimate relationships, as illustrated in Fig. 6 and also found by Vinther et al. (2010). Both the location and sign of correlation coefficients appear to vary through our three time intervals, despite being associated with rather similar mean summer NAO values. This difficulty to identify robust features in the three periods points to shifts in the location of the summer NAO centers of action, associated to reported changes in the North Atlantic summer mean circulation (Hurrell and Folland, 2002).

In winter, the correlation patterns with the NAO are clearly more robust (Fig. 7), although still subject to some spatial changes. For precipitation (Fig. 7a), only the negative correlations in the western Mediterranean region remain stable, while positive values over Scandinavia and western Russia appear for the last two periods, both characterised by a positive mean NAO state. The correlation patterns for temperature (Fig. 7b) show most robust features through time, with persistent positive values in eastern North America, northern Europe and negative ones around the Labrador Sea, North Africa and the Middle East. Note again that, some correlations become insignificant only during the first time interval, in this case over eastern Greenland and Siberia. Finally, a similar picture holds for the precipitation-weighted temperatures (Fig. 7c), the main difference being that the magnitudes of correlation are generally smaller than for temperature, and also more affected by local conditions, which is normal given the weighting effect of precipitation.

We note that the quality of the reanalysis might be weaker for the first period (1950-1970), prior to the satellite data assimilation. It is also possible that, during this period, the negative NAO-pattern has an influence over the NAO-climate relationship that would make it differ from the most recent periods, characterised by a positive NAO-pattern.

\subsection{Comparison between DJFM NAO- $T_{p}$ correlation and $\mathrm{NAO}-\delta^{18} \mathrm{O}$ correlation}

As stated in the introduction, water stable isotopes are integrated tracers of the water cycle, and the isotopic composition of precipitation itself is related not only to local condensation temperature, but also to all phase changes occurring from evaporation to condensation. Second order parameters (deuterium excess or ${ }^{17} \mathrm{O}$ excess) may provide evidence for changes in evaporation conditions. However, the observational records (precipitation monitoring) are too short to be used to analyse correlations between these parameters and the NAO, and therefore the relationships between the NAO and changes in moisture origin. For Greenland, where ice core records of past precipitation are available, numerous seasonally resolved $\delta^{18} \mathrm{O}$ records are available (Vinther et al., 2010), while only a few datasets of deuterium excess (Sodemann et al., 2008; Steen-Larsen et al., 2011) or ${ }^{17} \mathrm{O}$ excess (Landais et al., 2012), which require higher accuracy, are available. The most robust results have been produced for combined $\delta^{18} \mathrm{O}$ from several shallow ice cores. So far, based on observations, it has not been possible to quantify the impact of NAO on moisture sources and therefore the possible biases introduced in local climate- $\delta^{18} \mathrm{O}$ relationships. Yet, through the computation of moisture back-trajectories for Greenland precipitation, Sodemann et al. (2008) has identified SST (sea surface temperature) changes of up to $5^{\circ} \mathrm{C}$ related to positive versus negative NAO winter conditions, thus suggesting that processes other than condensation temperature are likely to impact the $\mathrm{NAO}-\delta^{18} \mathrm{O}$ relationship. We are therefore fully aware that relationships between NAO and $\delta^{18} \mathrm{O}$ can involve processes other than condensation temperature. To quantify these processes, we compare the pattern and strength of the correlation between NAO and $T_{p}$, with the pattern and strength of the correlation between NAO and precipitation $\delta^{18} \mathrm{O}$ from LMDZiso (Figs. $5 \mathrm{c}$ and $8 \mathrm{~b}$ ).

First, the LMDZiso model results are described (Fig. 5). Overall, the spatial features of the correlation patterns between the winter NAO and both $T_{p}$ and $\delta^{18} \mathrm{O}$ are rather coherent (Fig. 5c, d), with negative correlation values over parts of Greenland and NW North America (Labrador area), and positive values in northern Eurasia. However, there are clear differences regarding the actual locations for the significant values $(>0.35)$ over Greenland, as they occur near the eastern coast for $T_{p}$ and more in the western side for $\delta^{18} \mathrm{O}$, which is more consistent with the correlation pattern for precipitation. In Eurasia, the extent and the strength of the significant correlations are smaller in $\delta^{18} \mathrm{O}$ than in $T_{p}$, suggesting that other processes (e.g. changes in moisture sources, changes between condensation and surface temperature) act to reduce the imprint of NAO in $\delta^{18} \mathrm{O}$. This supports the idea that the investigation of the NAO- $T_{p}$ relationships provides an ideal test bed for investigating $\mathrm{NAO}-\delta^{18} \mathrm{O}$ relationships.

The LMDZiso NAO- $\delta^{18} \mathrm{O}$ and the NCEP and ERAinterim NAO- $T_{p}$ correlations are now compared to observations of NAO- $\delta^{18} \mathrm{O}$ correlations, using instrumental records of precipitation isotopic composition and Greenland ice cores. This comparison is strongly limited by the lack of consistency of the time frame where these observations are available (Supplement, Sect. B, Tables S1 and S2).

The GNIP data (Fig. 8; right column) confirm the simulated structure of winter NAO- $\delta^{18} \mathrm{O}$ relationships (Baldini et al., 2008), with positive correlations encountered in Western Europe, North America and Russia, and small, negative correlations over Iceland and Svalbard. No data are available to test the simulated negative NAO- $T_{p}$ correlation depicted by NCEP and ERA-interim for the extreme east of Siberia and for the Québec/Baffin Bay/Ellesmere Island area. The strongest correlation coefficients are obtained for Western 


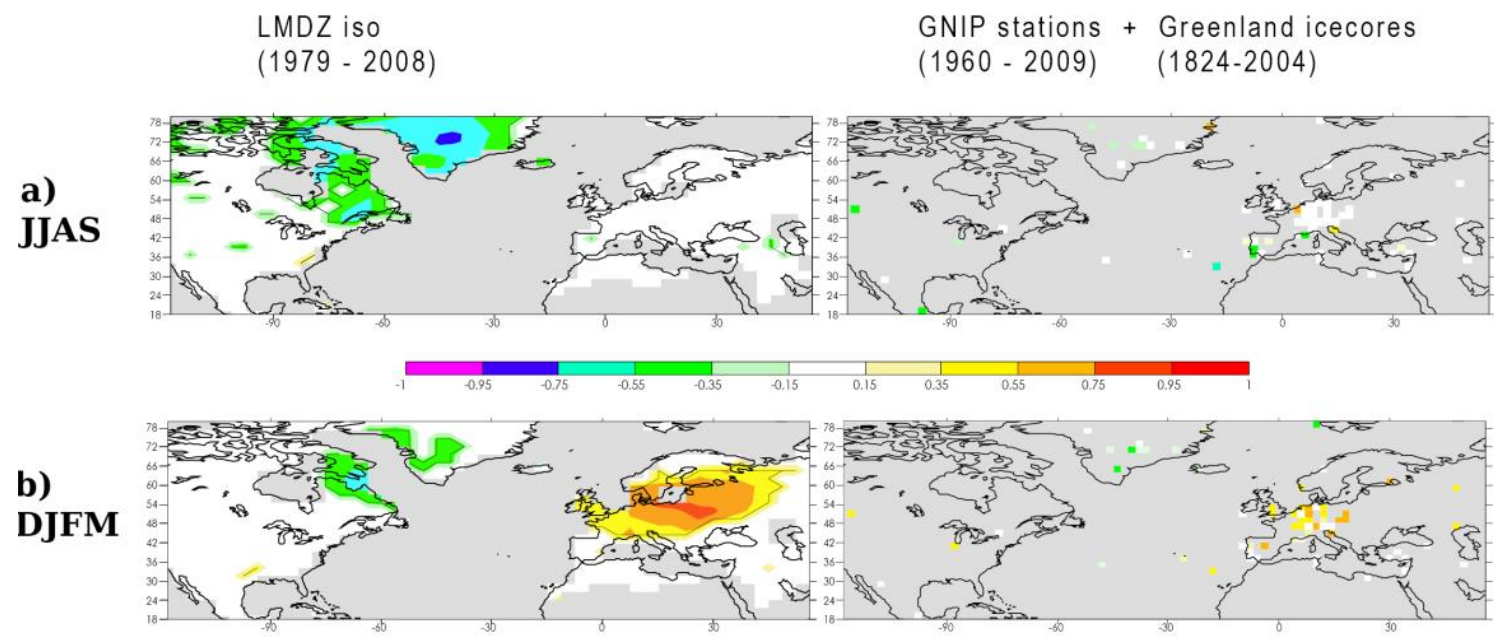

Fig. 8. Linear correlation coefficient between the respective (a) JJAS and (b) DJFM NAO indices and $\delta^{18} \mathrm{O}$ from GNIP and Greenland ice core data (right; see text and Supplement, Sect. C for details) and for LMDZiso (left); zoomed on the areas where observations are available. Note that a different colour scale is used compared to Figs. 4 and 5, which shows the signs of weak but significant correlations (light green and light yellow, with absolute correlation coefficients between 0.15 and 0.35 ). White areas indicate small (non significant) correlation coefficients.

and central Europe, with $R$ values up to 0.75 , and therefore comparable with the strength of the correlations produced in this area for $T_{p}$ and $\delta^{18} \mathrm{O}$ by NCEP, ERA-interim and LMDZiso. These strong correlations were also reported in several observational (Baldini et al., 2008) and modelling (Field, 2010; Langebroek et al., 2011; Sjolte et al., 2011) studies, which, however, often explored the anomalies between specific positive and negative NAO situations, rather than linear correlations, preventing us from making quantitative comparisons.

Winter signals extracted from southern and central Greenland ice cores (Vinther et al., 2010) systematically depict a negative correlation coefficient with $\mathrm{NAO}$, varying between -0.13 and -0.42 for the time intervals where raw data are available (Fig. 8b, Table S3). The comparison between the ice core signals and our results is also delicate because of the different time periods available, as most of the ice core records are only available prior to the 1970s. In NW Greenland, the new NEEM ice core shows no correlation between winter $\delta^{18} \mathrm{O}$ (one shallow ice core) and NAO for the last decades (Steen-Larsen et al., 2011). This ice core lies on an area of sharp gradients in atmospheric datasets (Figs. 5 and 8) where all datasets (CRU-NCEP, ERA-interim and LMDZiso) show large variations from significant negative correlation with local $T_{p}$ and $\delta^{18} \mathrm{O}$ to zero correlation. The stronger winter NAO correlation depicted by reanalyses and LMDZiso compared to the NEEM data could be explained by two possibilities: either all atmospheric models poorly capture the NW Greenland weather patterns and precipitation intermittency (in the Greenland area where annual precipitation is dominated by summer snowfall), or the NAO signal present in local temperature is masked in $\delta^{18} \mathrm{O}$ due to changes in moisture source, while at the same time LMDZiso fails to capture these effects. The latter option cannot be excluded, as in situ, summer surface water vapour isotopic composition shows large subseasonal deuterium excess variations associated with different air mass origins, which further cannot be captured by LMDZiso (Steen-Larsen et al., 2013).

\section{Conclusions and perspectives}

The precipitation intermittency biases and their implications for correlations with the North Atlantic Oscillation have been explored, using two atmospheric analyses and one atmospheric model equipped with water stable isotopes.

Summer NAO appears to leave a discernable imprint on temperature and isotopes in very specific areas (NE and NW North America, Greenland, E Siberia), but precipitation intermittency reduces the spatial extent and the magnitude of the correlation with temperature. From existing isotopic datasets, LMDZiso seems to overestimate the strength of the summer NAO imprint on Greenland water stable isotopes, although it might be just an artefact of the particular choice for the NAO index. Indeed, the alternative definition as the leading PC for North Atlantic SLP (Fig. S3), which is more faithful to the actual position of the centers of action during the summer, shows a drastic decrease in the amplitude of these Greenland correlations. We therefore remain extremely cautious about reconstructions of summer NAO using precipitation-sensitive archives. Further investigations should be performed using daily meteorological and water vapour isotopic data combined with back trajectories, because of the uncertainties on daily precipitation amounts in atmospheric models. 
More robust conclusions can be achieved for winter NAO. For that season, precipitation intermittency only weakly affects the strong imprint of NAO on surface air temperature, and NAO-climate relationships further appear stable throughout the investigated datasets and time periods. The correlations between winter NAO and $T_{p}$ likely capture correctly the actual signs and patterns of $\mathrm{NAO}-\delta^{18} \mathrm{O}$ correlation. However, other factors do affect $\delta^{18} \mathrm{O}$ and may alter the relationship observed for $T_{p}$. The NAO signal in central European $\delta^{18} \mathrm{O}$ appears as a robust feature, observed from the long GNIP data and captured in all atmospheric simulations with the right location and strength. The same conclusion applies to the negative correlation between NAO and Greenland winter $\delta^{18} \mathrm{O}$. Other areas depict a strong simulated NAO imprint which cannot be compared to direct observations (e.g. North America, Russia). Overall, the consistency of several of our findings between NCEP, ERA-interim and LMDZiso, and with daily station data, suggest that they are robust. We have also shown that they are not affected by a different definition of NAO accounting for changes in action centers.

Our study shows the potential of using direct (ice cores) or indirect archives of winter precipitation $\delta^{18} \mathrm{O}$ for reconstructing past changes in the winter NAO index. Many published reconstructions referenced in Sect. 1 rely on precipitation or temperature sensitive proxies. The winter NAOprecipitation relationship does not have large-scale characteristics that are robust over different atmospheric models and time periods, apart from its negative imprint in SW Greenland and Mediterranean area, and positive imprint in northern Europe. The NCEP data shows robust features in the winter NAO- $T_{p}$ relation for three different time periods of $20 \mathrm{yr}$, all highlighting four main influence regions characterised by negative correlations from Labrador to the Baffin Bay and also in the North of Africa and the Middle East, and with positive values in the North of Europe and Russia, as well as in eastern North America. However, the extent and strength of these correlations change with time, probably as a result of the spatial variability in the centers of action of the NAO. We suggest that the $T_{p}$ variable (from in situ meteorological data, or from analyses) may present some advantages as a target for calibrating $\delta^{18} \mathrm{O}$ proxy records, rather than the mean winter temperature, because of the magnitude and variability of the precipitation intermittency bias (Fig. 3). Of course, obtaining pure winter $\delta^{18} \mathrm{O}$ records from natural archives other than ice cores is extremely difficult. However, deposition and archiving processes may propagate and preserve the winter NAO imprint in precipitation $\delta^{18} \mathrm{O}$ into summer or annual mean signals. This could be the case for tree ring cellulose, for instance if soil moisture is refilled by snow melt in mountainous or high elevation areas. Such processes could explain why, despite the influence of summer climate on tree growth, a link with the winter NAO is found in tree ring cellulose $\delta^{18} \mathrm{O}$ from Siberia, where data from Yakoutia appear in antiphase with those from Taimyr, and in phase with the variability depicted in Greenland ice cores (Sidorova et al., 2010).
Annually resolved speleothems may also preserve a winter precipitation $\delta^{18} \mathrm{O}$ signal, despite the complexity of infiltration and calcification processes.

Compiling records of past precipitation $\delta^{18} \mathrm{O}$ interannual variability derived from different natural archives is the next step required for using them towards NAO reconstructions. The present study enables us to identify the regions where precipitation weighted temperature and $\delta^{18} \mathrm{O}$ exhibit the maximum correlation or negative correlation with the NAO over the recent instrumental era. The combination of records from the Mediterranean area (where winter precipitation is important), with records from central and northern Europe, Québec, Greenland and Russia/Siberia/Yakoutia has the potential to allow new, more robust reconstructions of the NAO. This could be achieved using precipitation $\delta^{18} \mathrm{O}$ estimated using lake sediments, speleothems, ice cores and tree ring cellulose, albeit with the difficulties related to the seasonality and complexity of each archiving process. Multicentennial simulations conducted with coupled ocean-atmosphere models equipped with water stable isotopes could also be used to assess the stability of the NAO- $\delta^{18} \mathrm{O}$ relationships through time, in response to different forcings and under different states of e.g. the Atlantic Multidecadal Oscillation. Although restricted to the last decades, our study suggests systematically combining at least data from Europe and from Greenland in order to capture the structure of NAO imprints.

\section{Supplementary material related to this article is available online at: http://www.clim-past.net/9/871/2013/ cp-9-871-2013-supplement.pdf.}

Acknowledgements. This study has been funded by the French Agence Nationale de la Recherche ANR CEPS GREENLAND project. We thank the three anonymous reviewers and also the participants to the ESF conference "Modes of variability in the climate system" for constructive comments and feedbacks on this work. The support of Jean-Yves Peterschmitt for figure processing is also acknowledged as well as Ralph Beeby for his careful read-through.

This is a LSCE publication 4579.

Edited by: J. Luterbacher

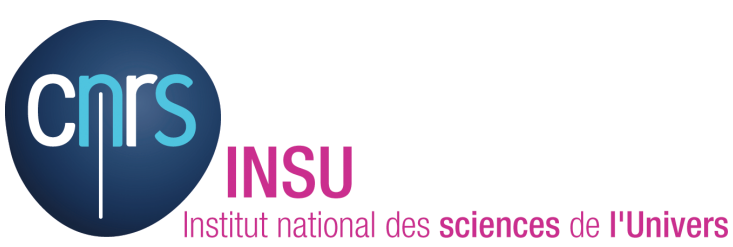

The publication of this article is financed by CNRS-INSU. 


\section{References}

Andersson, E., Holm, E., Bauer, P., Bejaars, A., Kelly, G. A., McNally, A. P., Simmons, A. J., Thepaut, J. N., and Tompkins, A. M.: Analysis and forecast impact of the main humidity observing systems, Q. J. Roy. Meteorol. Soc., 133, 1473-1485, doi:10.1002/qj.112, 2007.

Appenzeller, C., Stocker, T. F., and Anklin, M.: North atlantic oscillation dynamics recorded in greenland ice cores, Science, 282, 446-449, 1998.

Baker, A., Smart, P. L., Edwards, R. L., and Richards, D. A.: Annual growth in a cave stalagmite, Nature, 364, 518-520, doi:10.1038/364518a0, 1993.

Baker, A., Proctor, C. J., and Barnes, W. L.: Stalagmite lamina doublets: A 1000 year proxy record of severe winters in northwest scotland?, Int. J. Climatol., 22, 1339-1345, doi:10.1002/joc.800, 2002.

Baldini, L. M., McDermott, F., and Baldini, J. U. L.: Detecting nao-mode variability in high-resolution speleothem isotope records, Geochim. Cosmochim. Ac., 70, A31-A31, doi:10.1016/j.gca.2006.06.170, 2006.

Baldini, L. M., McDermott, F., Foley, A. M., and Baldini, J. U. L.: Spatial variability in the european winter precipitation $\delta^{18} \mathrm{O}$ nao relationship: Implications for reconstructing nao-mode climate variability in the holocene, Geophys. Res. Lett., 35, L04709, doi:10.1029/2007GL032027, 2008.

Barlow, L. K., White, J. W. C., Barry, R. G., Rogers, J. C., and Grootes, P. M.: The north atlantic oscillation signature in deuterium and deuterium excess signals in the greenland ice sheet project 2 ice core, 1840-1970, Geophys. Res. Lett., 20, 29012904, 1993.

Bladé, I., Fortuny, D., van Oldenborgh, G. J., and Liebmann, B.: The summer north atlantic oscillation in cmip3 models and related uncertainties in projected summer drying in europe, J. Geophys. Res.-Atmos., 117, D16104, doi:10.1029/2012jd017816, 2012.

Bosilovich, M. G., Chen, J. Y., Robertson, F. R., and Adler, R. F.: Evaluation of global precipitation in reanalyses, J. Appl. Meteorol. Climatol., 47, 2279-2299, doi:10.1175/2008jamc1921.1, 2008.

Casty, C., Raible, C., Stocker, T., Wanner, H., and Luterbacher, J.: A european pattern climatology 1766-2000, Clim. Dynam., 29, 791-805, doi:10.1007/s00382-007-0257-6, 2007.

Chen, L. L., Johannessen, O. M., Wang, H. J., and Ohmura, A.: Accumulation over the greenland ice sheet as represented in reanalysis data, Adv. Atmos. Sci., 28, 1030-1038, doi:10.1007/s00376010-0150-9, 2011.

Cook, E. R., D’Arrigo, R. D., and Mann, M. E.: A well-verified, multiproxy reconstruction of the winter north atlantic oscillation index since ad 1400, J. Climate, 15, 1754-1764, 2002.

Dee, D. P., Uppala, S. M., Simmons, A. J., Berrisford, P., Poli, P., Kobayashi, S., Andrae, U., Balmaseda, M. A., Balsamo, G., Bauer, P., Bechtold, P., Beljaars, A. C. M., van de Berg, L., Bidlot, J., Bormann, N., Delsol, C., Dragani, R., Fuentes, M., Geer, A. J., Haimberger, L., Healy, S. B., Hersbach, H., Holm, E. V., Isaksen, L., Kallberg, P., Kohler, M., Matricardi, M., McNally, A. P., Monge-Sanz, B. M., Morcrette, J. J., Park, B. K., Peubey, C., de Rosnay, P., Tavolato, C., Thepaut, J. N., and Vitart, F.: The erainterim reanalysis: Configuration and performance of the data assimilation system, Q. J. Roy. Meteorol. Soc., 137, 553-597, doi:10.1002/qj.828, 2011.
Delworth, T. L. and Mann, M. E.: Observed and simulated multidecadal variability in the northern hemisphere, Clim. Dynam., 16, 661-676, doi:10.1007/s003820000075, 2000.

Divine, D. V., Sjolte, J., Isaksson, E., Meijer, H. A. J., van de Wal, R. S. W., Martma, T., Pohjola, V., Sturm, C., and Godtliebsen, F.: Modelling the regional climate and isotopic composition of svalbard precipitation using remoiso: A comparison with available gnip and ice core data, Hydrol. Process., 25, 3748-3759, doi:10.1002/hyp.8100, 2011.

Felis, T. and Rimbu, N.: Mediterranean climate variability documented in oxygen isotope records from northern red sea corals - a review, Global and Planet. Change, 71, 232-241, doi:10.1016/j.gloplacha.2009.10.006, 2010.

Field, R. D.: Observed and modeled controls on precipitation delta o-18 over europe: From local temperature to the northern annular mode, J. Geophys. Res.-Atmos., 115, D12101, doi:10.1029/2009jd013370, 2010.

Fleitmann, D., Cheng, H., Badertscher, S., Edwards, R. L., Mudelsee, M., Göktürk, O. M., Fankhauser, A., Pickering, R., Raible, C. C., Matter, A., Kramers, J., and Tüysüz, O.: Timing and climatic impact of greenland interstadials recorded in stalagmites from northern turkey, Geophys. Res. Lett., 36, L19707, doi:10.1029/2009g1040050, 2009.

Folland, C. K., Knight, J., Linderholm, H., Fereday, D., Ineson, S., and Hurrell, J. W.: The summer north atlantic oscillation: Past, present and future, J. Climate, 22, 1082-1103, 2009.

Genty, D.: Seasonal alternations in the internal structure of stalagmites; importance for the reconstitution of continental paleoenvironments, CR. Acad. Sci. II, 317, 1229-1236, 1993.

Glueck, M. F. and Stockton, C. W.: Reconstruction of the north atlantic oscillation, 1429-1983, Int. J. Climatol., 21, 1453-1465, 2001.

Hangartner, S., Kress, A., Saurer, M., Frank, D., and Leuenberger, M.: Methods to merge overlapping tree-ring isotope series to generate multi-centennial chronologies, Chem. Geol., 294-295, 127-134, doi:10.1016/j.chemgeo.2011.11.032, 2012.

Hirschi, M., Seneviratne, S. I., Alexandrov, V., Boberg, F., Boroneant, C., Christensen, O. B., Formayer, H., Orlowsky, B., and Stepanek, P.: Observational evidence for soil-moisture impact on hot extremes in southeastern europe, Nat. Geosci., 4, 1721, doi:10.1038/ngeo1032, 2011.

Hurrell, J. W.: Decadal trends in the north atlantic oscillation: Regional temperatures and precipitation, Science, 269, 676-679, 1995.

Hurrell, J. W. and Folland, C. K.: A change in the summer atmospheric circulation over the north atlantic, CLIVAR Exchanges, 25, 52-54, 2002.

Hurrell, J. W., Kushnir, Y., Ottersen, G., and Visbeck, L.: An overview of the north atlantic oscillation, in: The north atlantic oscillation: Climate significance and environmental impact, edited by: Hurrell, Y., Kushnir, Y., Ottersen, G., and Visbeck, M., Geophysical Monoghraph Series, 1-35, 2003.

IPCC: Climate Change 2007 - the physical science basis, Fourth assessment report, Cambridge University Press, Cambridge, 1009 pp., 2007.

Janowiak, J. E., Bauer, P., Wang, W. Q., Arkin, P. A., and Gottschalck, J.: An evaluation of precipitation forecasts from operational models and reanalyses including precipitation variations associated with mjo activity, Mon. Weather Rev., 138, 
4542-4560, doi:10.1175/2010mwr3436.1, 2010.

Jones, P. D., Jonsson, T., and Wheeler, D.: Extension to the north atlantic oscillation using early instrumental pressure observations from gibraltar and south-west iceland, Int. J. Climatol., 17, 14331450, 10.1002/(sici)1097-0088(19971115)17:13;1433::aidjoc 203 i3.0.co;2-p, 1997.

Jouzel, J.: Water stable isotopes: Atmospheric composition and applications in polar ice core studies, in: Treatise on geochemistry, edited by: Keeling, R. F., Elsevier, 213-243, 2003.

Jung, T., Balsamo, G., Bechtold, P., Beljaars, A. C. M., Kohler, M., Miller, M. J., Morcrette, J. J., Orr, A., Rodwell, M. J., and Tompkins, A. M.: The ecmwf model climate: Recent progress through improved physical parametrizations, Q. J. Roy. Meteorol. Soc., 136, 1145-1160, doi:10.1002/qj.634, 2010.

Kalnay, E., Kanamitsu, M., and Kistler, R., Collins, W., Deaven, D., Gandin, L., Iredell, M., Saha, S., White, G., Woollen, J., Zhu, Y., Chelliah, M., Ebisuzaki, W., Higgins, W., Janowiak, J., Mo, K. C., Ropelewski, C., Wang, J., Leetmaa, A., Reynolds, R., Jenne, R., and Joseph, D.: The ncep/ncar 40-year reanalyses project, B. Am. Meteorol. Soc., 77, 437-431, 1996.

Küttel, M., Luterbacher, J., and Wanner, H.: Multidecadal changes in winter circulation-climate relationship in europe: Frequency variations, within-type modifications, and long-term trends, Clim. Dynam., 36, 957-972, doi:10.1007/s00382-009-0737-y, 2011.

Kurita, N.: Origin of arctic water vapor during the icegrowth season, Geophys. Res. Lett., 38, L02709, doi:10.1029/2010g1046064, 2011.

Landais, A., Steen-Larsen, H. C., Guillevic, M., MassonDelmotte, V., Vinther, B., and Winkler, R.: Triple isotopic composition of oxygen in surface snow and water vapor at neem (greenland), Geochim. Cosmochim. Ac., 77, 304-316, doi:10.1016/j.gca.2011.11.022, 2012.

Langebroek, P. M., Werner, M., and Lohmann, G.: Climate information imprinted in oxygen-isotopic composition of precipitation in Europe, Earth Planet. Sci. Lett., 311, 144-154, doi:10.1016/j.epsl.2011.08.049, 2011.

Lehner, F., Raible, C. C., and Stocker, T. F.: Testing the robustness of a precipitation proxy-based north atlantic oscillation reconstruction, Quaternary Sci. Rev., 45, 85-94, doi:10.1016/j.quascirev.2012.04.025, 2012.

Luterbacher, J., Schmutz, C., Gyalistras, D., Xoplaki, E., and Wanner, H.: Reconstruction of monthly nao and eu indices back to ad 1675, Geophys. Res. Lett., 26, 2745-2748, 1999.

Luterbacher, J., Rickli, R., Tinguely, C., Xoplaki, E., Schüpach, E., Dietriche, D., Hüsler, J., Ambühl, M., Pfister, C., Beeli, P., Dietriche, U., Danneckler, A., Davies, T. D., P. D. Jones, Slonosky, V., Ogilvie, A. E. J., Maheras, P., Kolyva-Machera, F., Martin-Vide, J., Barriendos, M., Alcoforado, M. J., Nunes, M. F., Jónsson, T., Glaser, R., Jacobeit, J., Beck, C., Philipp, A., Beyer, U., Kaas, E., Schmith, T., Bärring, L., Jönsson, P., Rácz, L., and Wanner, H.: Monthly mean pressure reconstruction for the late maunder minimum period (ad 1675-1715), Int. J. Climatol., 20, 1049-1066, 2000.

Luterbacher, J., Xoplaki, E., Dietrich, D., Jones, P. D., Davies, T. D., Portis, D., Gonzalez-Rouco, J. F., von Storch, H., Gyalistras, D., Casty, C., and Wanner, H.: Extending north atlantic oscillation reconstructions back to 1500, Atmos. Sci. Lett., 2, 114-124, doi:10.1006/asle.2002.0047, 2001.
Luterbacher, J., Xoplaki, E., Dietrich, D., Rickli, R., Jacobeit, J., Beck, C., Gyalistras, D., Schmutz, C., and Wanner, H.: Reconstruction of sea level pressure fields over the eastern north altantic and europe back to 1500, Clim. Dynam., 18, 545-561, 2002.

Ma, L. J., Zhang, T., Frauenfeld, O. W., Ye, B. S., Yang, D. Q., and Qin, D. H.: Evaluation of precipitation from the era-40, ncep1 , and ncep-2 reanalyses and cmap-1, cmap-2, and gpcp-2 with ground-based measurements in china, J. Geophys. Res.-Atmos., 114, D09105, doi:10.1029/2008jd011178, 2009.

Maignan, F., Bréon, F.-M., Chevallier, F., Viovy, N., Ciais, P., Garrec, C., Trules, J., and Mancip, M.: Evaluation of a Global Vegetation Model using time series of satellite vegetation indices, Geosci. Model Dev., 4, 1103-1114, doi:10.5194/gmd-4-11032011, 2011.

Mitchell, T. D. and Jones, P. D.: An improved method of constructing a database of monthly climate observations and associated high-resolution grids, Int. J. Climatol., 25, 693-712, 2005.

Munoz, A., Sen, A. K., Sancho, C., and Genty, D.: Wavelet analysis of late holocene stalagmite records from ortigosa caves in northern spain, J. Cave Karst Stud., 71, 63-72, 2009.

Persson, A., Langen, P. L., Ditlevsen, P., and Vinther, B. M.: The influence of precipitation weighting on interannual variability of stable water isotopes in greenland, J. Geophys. Res.-Atmos., 116, D20120, doi:10.1029/2010jd015517, 2011.

Pinto, J. G. and Raible, C. C.: Past and recent changes in the north atlantic oscillation, Wiley Interdisciplinary Reviews: Climate Change, 3, 79-90, doi:10.1002/wcc.150, 2012.

Proctor, C. J., Baker, A., Barnes, W. L., and Gilmour, R. A.: A thousand year speleothem proxy record of north atlantic climate from scotland, Clim. Dynam., 16, 815-820, doi:10.1007/s003820000077, 2000.

Raible, C., Casty, C., Luterbacher, J., Pauling, A., Esper, J., Frank, D., Büntgen, U., Roesch, A., Tschuck, P., Wild, M., Vidale, P.L., Schär, C., and Wanner, H.: Climate variability-observations, reconstructions, and model simulations for the atlantic-european and alpine region from 1500-2100 ad, Climatic Change, 79, 929, doi:10.1007/s10584-006-9061-2, 2006.

Risi, C., Bony, S., Vimeux, F., and Jouzel, J.: Water-stable isotopes in the lmdz4 general circulation model: Model evaluation for present-day and past climates and applications to climatic interpretations of tropical isotopic records, J. Geophys. Res.-Atmos., 115, D12118, doi:10.1029/2009jd013255, 2010.

Rozanski, K., Araguas-Araguas, L., and Gonfiantini, R.: Isotopic patterns in modern global precipitation, in: Climate change in continental isotopic records, edited by: P. K. Swart, K. L. L., McKenzie, J., and Savin, S., AGU Geophys. Monogr., 1-37, 1993.

Saurer, M., Kress, A., Leuenberger, M., Rinne, K. T., Treydte, K. S., and Siegwolf, R. T. W.: Influence of atmospheric circulation patterns on the oxygen isotope ratio of tree rings in the alpine region, J. Geophys. Res.-Atmos., 117, D05118, doi:10.1029/2011jd016861, 2012.

Serreze, M. C. and Hurst, C. M.: Representation of mean arctic precipitation from ncep-ncar and era reanalyses, J. Climate, 13, 182 201, doi:10.1175/1520-0442(2000)013 ¡0182:romapf $i 2.0 . c o ; 2$, 2000.

Sidorova, O. V., Siegwolf, R. T. W., Saurer, M., Naurzbaev, M. M., Shashkin, A. V., and Vaganov, E. A.: Spatial patterns of climatic changes in the eurasian north reflected in siberian larch tree-ring 
parameters and stable isotopes, Global Change Biol., 16, 10031018, doi:10.1111/j.1365-2486.2009.02008.x, 2010.

Sime, L. C., Tindall, J. C., Wolff, E. W., Connolley, W. M., and Valdes, P. J.: Antarctic isotopic thermometer during a $\mathrm{CO} 2$ forced warming event, J. Geophys. Res.-Atmos., 113, D24119, doi:10.1029/2008jd010395, 2008.

Sjolte, J., Hoffmann, G., Johnsen, S. J., Vinther, B. M., Masson-Delmotte, V., and Sturm, C.: Modeling the water isotopes in greenland precipitation 1959-2001 with the meso-scale model remo-iso, J. Geophys. Res., 116, D18105, doi:10.1029/2010jd015287, 2011.

Sodemann, H., Masson-Delmotte, V., Schwierz, C., Vinther, B. M., and Wernli, H.: Interannual variability of greenland winter precipitation sources: 2 . Effects of north atlantic oscillation variability on stable isotopes in precipitation, J. Geophys. Res.-Atmos., 113, D12111, doi:10.1029/2007jd009416, 2008.

Steen-Larsen, H. C., Masson-Delmotte, V., Sjolte, J., Johnsen, S. J., Vinther, B. M., Breon, F. M., Clausen, H. B., Dahl-Jensen, D., Falourd, S., Fettweis, X., Gallee, H., Jouzel, J., Kageyama, M., Lerche, H., Minster, B., Picard, G., Punge, H. J., Risi, C., Salas, D., Schwander, J., Steffen, K., Sveinbjornsdottir, A. E., Svensson, A., and White, J.: Understanding the climatic signal in the water stable isotope records from the neem shallow firn/ice cores in northwest greenland, J. Geophys. Res.-Atmos., 116, D06108, doi:10.1029/2010jd014311, 2011.

Steen-Larsen, H. C., Johnsen, S. J., Masson-Delmotte, V., Stenni, B., Risi, C., Sodemann, H., Balslev-Clausen, D., Blunier, T., Dahl-Jensen, D., Ellehøj, M. D., Falourd, S., Gkinis, V., Grindsted, A., Jouzel, J., Popp, T., Sheldon, S., Simonsen, S. B., Sjolte, J., Steffensen, J. P., Sperlich, P., Sveinbjörnsdóttir, A. E., Vinther, B. M., and White, J. W. C.: Continuous monitoring of summer surface water vapour isotopic composition above the Greenland Ice Sheet, Atmos. Chem. Phys. Discuss., 13, 1399-1433, doi:10.5194/acpd-13-1399-2013, 2013.

Sturm, C., Zhang, Q., and Noone, D.: An introduction to stable water isotopes in climate models: benefits of forward proxy modelling for paleoclimatology, Clim. Past, 6, 115-129, doi:10.5194/cp-6-115-2010, 2010.

Tan, M., Baker, A., Genty, D., Smith, C., Esper, J., and Cai, B. G.: Applications of stalagmite laminae to paleoclimate reconstructions: Comparison with dendrochronology/climatology, Quaternary Sci. Rev., 25, 2103-2117, doi:10.1016/j.quascirev.2006.01.034, 2006.

Theakstone, W. H.: A seven-year study of oxygen isotopes in daily precipitation at a site close to the arctic circle, tustervatn, norway: Trajectory analysis and links with the north atlantic oscillation, Atmos. Environ., 45, 5101-5109, doi:10.1016/j.atmosenv.2011.06.034, 2011.

Treydte, K., Frank, D., Esper, J., Andreu, L., Bednarz, Z., Berninger, F., Boettger, T., D’Alessandro, C. M., Etien, N., Filot, M., Grabner, M., Guillemin, M. T., Gutierrez, E., Haupt, M., Helle, G., Hilasvuori, E., Jungner, H., Kalela-Brundin, M., Krapiec, M., Leuenberger, M., Loader, N. J., Masson-Delmotte, V., Pazdur, A., Pawelczyk, S., Pierre, M., Planells, O., Pukiene, R., Reynolds-Henne, C. E., Rinne, K. T., Saracino, A., Saurer, M., Sonninen, E., Stievenard, M., Switsur, V. R., Szczepanek, M., Szychowska-Krapiec, E., Todaro, L., Waterhouse, J. S., Weigl, M., and Schleser, G. H.: Signal strength and climate calibration of a european tree-ring isotope network, Geophys. Res. Lett., 34,
L24302, doi:10.1029/2007g1031106, 2007.

Trouet, V., Esper, J., Graham, N. E., Baker, A., Scourse, J. D., and Frank, D.: Persistent positive north atlantic oscillation mode dominated the medieval climate anomaly, Science, 324, 78-80, 2009.

Trouet, V., Scourse, J. D., and Raible, C. C.: North atlantic storminess and atlantic meridional overturning circulation during the last millennium: Reconciling contradictory proxy records of nao variability, Global Planet. Change, 84-85, 48-55, doi:10.1016/j.gloplacha.2011.10.003, 2012.

Uppala, S. M., Kallberg, P. W., Simmons, A. J., Andrae, U., Bechtold, V. D., Fiorino, M., Gibson, J. K., Haseler, J., Hernandez, A., Kelly, G. A., Li, X., Onogi, K., Saarinen, S., Sokka, N., Allan, R. P., Andersson, E., Arpe, K., Balmaseda, M. A., Beljaars, A. C. M., Van De Berg, L., Bidlot, J., Bormann, N., Caires, S., Chevallier, F., Dethof, A., Dragosavac, M., Fisher, M., Fuentes, M., Hagemann, S., Holm, E., Hoskins, B. J., Isaksen, L., Janssen, P., Jenne, R., McNally, A. P., Mahfouf, J. F., Morcrette, J. J., Rayner, N. A., Saunders, R. W., Simon, P., Sterl, A., Trenberth, K. E., Untch, A., Vasiljevic, D., Viterbo, P., and Woollen, J.: The era-40 re-analysis, Q. J. Roy. Meteorol. Soc., 131, 2961-3012, doi:10.1256/qj.04.176, 2005.

van der Ent, R. J., Savenije, H. H. G., Schaefli, B., and Steele-Dunne, S. C.: Origin and fate of atmospheric moisture over continents, Water Resour. Res., 46, W09525, doi:10.1029/2010wr009127, 2010.

Vinther, B. M., Johnsen, S. J., Andersen, K. K., Clausen, H. B., and Hansen, A. W.: Nao signal recorded in the stable isotopes of greenland ice cores, Geophys. Res. Lett., 30, 1387-1390, 2003 a.

Vinther, B. M., Andersen, K. K., Hansen, A. W., Schmith, T., and Jones, P. D.: Improving the Gibraltar/Reykjavik nao index, Geophys. Res. Lett., 30, 2222, doi:10.1029/2003gl018220, 2003 b.

Vinther, B. M., Jones, P. D., Briffa, K. R., Clausen, H. B., Andersen, K. K., Dahl-Jensen, D., and Johnsen, S. J.: Climatic signals in multiple highly resolved stable isotope records from greenland, Quaternary Sci. Rev., 29, 522-538, 2010.

Wanner, H., Brönnimann, S., Casty, C., Gyalistras, D., Luterbacher, J., Schmutz, C., Stephenson, D. B., and Xoplaki, E.: North atlantic oscillation - concepts and studies, Surv. Geophys., 22, 321-382, 2001.

Yoshimori, M., Raible, C., Stocker, T., and Renold, M.: On the interpretation of low-latitude hydrological proxy records based on maunder minimum aogcm simulations, Clim. Dynam., 27, 493513, doi:10.1007/s00382-006-0144-6, 2006.

Zorita, E. and González-Rouco, F.: Are temperature-sensitive proxies adequate for north atlantic oscillation reconstructions?, Geophys. Res. Lett., 29, 4841-4844, doi:10.1029/2002g1015404, 2002. 